\title{
Rapid Mapping for Simple Flood Mitigation Using Commercial Drone at Way Galih Village, Lampung, Indonesia
}

\author{
Arif Rohman ${ }^{1,2^{*}}$, Dwi Bayu Prasetya ${ }^{3}$ \\ ${ }^{1}$ Geomatic Engineering, Institut Teknologi Sumatera, Way Hui, Lampung, 35365 \\ ${ }^{2}$ School of Geography, University of Leeds, Leeds, LS2 9JT, United Kingdom \\ ${ }^{3}$ Regional and City Planning, Institut Teknologi Sumatera, Way Hui, Lampung 35365 \\ *) Corresponding Author (e-mail: arif@gt.itera.ac.id)
}

Received: 08 July 2019 / Accepted: 02 August 2019 / Published: 03 August 2019

\begin{abstract}
The process to alleviate flood risk, especially flood from a river that occurs excessively in Indonesia, requires a new approach. The attempt to reduce the risk along with the development of technology is by utilising commercial drones and rapid mapping methods for mapping flood plain area. With the rapid mapping method, the flood mitigation process in the village area can be done quickly. The activity carried out was to map the location of possible flooding in the Way Galih Village and case analysis to determine the location of the biogas digester together with the village government authority. The results of the study show that the data acquisition process and aerial photo processing can be carried out within one day and the village policymaker can quickly make policies and decisions about where to place the biogas digester.
\end{abstract}

Keywords: flood mitigation, rapid mapping, commercial drones, biogas.

\begin{abstract}
Abstrak. Proses pengurangan resiko banjir, terutama banjir sungai yang banyak terjadi di Indonesia memerlukan pendekatan baru. Terobosan yang dapat dilakukan saat ini seiring dengan perkembangan teknologi adalah dengan memanfaatkan drone komersil dan metode rapid mapping. Dengan metode rapid maping, proses mitigasi banjir di wilayah desa dapat dilakukan dengan cepat. Kegiatan yang dilakukan adalah memetakan lokasi kemungkinan banjir di lokasi Desa Waygalih dan case analysis penentuan lokasi digester biogas bersama dengan perangkat pemerintahan desa. Hasil penelitian menunjukan proses akuisisi data dan pengolahan foto udara dapat dilakukan dalam waktu 1 hari sehingga pihak desa dapat dengan cepat mengambil kebijakan dan keputusan dalam penentuan lokasi digester biogas.
\end{abstract}

Kata kunci: mitigasi banjir, rapid mapping, drone komersil, biogas.

\section{Introduction}

The general concept of how to overcome disaster risk is known as Disaster Risk Reduction (DRR). United Nations, through the UN International Strategy for Disaster Reduction (UNISDR) introduce standard DRR concept as a common framework that can be used by all countries as a reference for making more specific disaster solutions. UNISDR(2004) define the DRR as "the conceptual framework of elements considered with the possibilities to minimise vulnerabilities and disaster risks throughout a society, to avoid (prevention) or to limit (mitigation and preparedness) the adverse impacts of hazards, within the broad context of sustainable development". The first global framework as a guide to the implementation of DRR resulted in the Hyogo Conference year in 2005. The conference produces the Hyogo Framework 2005-2015 as a global framework for all countries. Hyogo Framework then continued by The Sendai 
Framework from 2015-2030. This new framework emerged because of the need to understand the complexity of the DRR in this century (Aitsi-Selmi et al., 2015). One form of complexity is the aspect of geographical variability such as in the form of an archipelagic country. This characteristic makes the DRR process require a location-specific model. The DRR process requires both physical adaptation (normalisation or naturalisation) and attention to social factors (capacity building and resilience). Asia-Pacific countries have high enthusiasm for the Sendai Framework DRR, including Indonesia which has prepared a roadmap on how this framework can support risk management at the local level (Wahlström, 2015). The key to good DRR implementation is that DRR needs systematic efforts to reduce causal factor of disasters. It is mean if more data on causal factors can be identified and analysed, DRR will be better. One of the rising technologies that can help to identified flood risk area is 3D map derived from Unmanned Aerial Vehicle (UAV) or commonly called drone.

Technological advances in mapping and spatial data processing have led to easier spatial modelling and spatial analysis. Nowadays the development of disaster area mapping technology through remote sensing can be done not only through remote sensing satellites (Smith, 1998) or planned, which can estimate inundation area and delineate flood boundaries. Radar altimeters show great promise for directly measuring stage variation in large rivers. It also appears to be possible to obtain estimates of river discharge from space, using ground measurements and satellite data to construct empirical curves that relate water surface area to discharge. Extrapolation of these curves to ungauged sites may be possible for the special case of braided rivers. Where clouds, trees and floating vegetation do not obscure the water surface, high-resolution visible/infrared sensors provide good delineation of inundated areas. Synthetic aperture radar (SAR but also through Unmanned Aerial Vehicle (UAV) or so-called drone (Feng, Liu, \& Gong, 2015; Griffin, 2014). Mapping with a drone for mapping disaster areas such as floods and landslides is arising nowadays because the process is fast and can cover most of the, if not all, impact area. In the phase of disaster, drone can help in every phase from prevention to map the high risk area, in response phase to help provide real time footage of the evacuation, and to help provide new map (especially terrain map) in the recovery stage (Griffin, 2014). In every phase, the mapping process needs to be executed in the short period. The process of fast mapping the disaster location using drones is commonly called rapid mapping (Tampubolon \& Reinhardt, 2015) geospatial data plays an important role to serve as a framework for decision support system. As one component of basic geospatial data, large scale topographical maps are mandatory in order to enable geospatial analysis within quite a number of societal challenges. The increasing role of geoinformation in disaster management nowadays consequently needs to include geospatial aspects on its analysis. Therefore different geospatial datasets can be combined in order to produce reliable geospatial analysis especially in the context of disaster preparedness and emergency response. A very well-known issue in this context is the fast delivery of geospatial relevant data which is expressed by the term \u201cRapid Mapping $\backslash u 201 d$. Unmanned Aerial Vehicle (UAV. Combine with Geographic Information System (GIS), we can have powerful tools to help mitigate the flood plain or flood risk area. UAV also can be combined with another tool such as Interferometric Synthetic Aperture Radar (IFSAR) to produce the fast and good quality map for disaster management like volcanic activity (Tampubolon \& Reinhardt, 2015)geospatial data plays an important role to serve as a framework for decision support system. As one component of basic geospatial data, large scale topographical maps are mandatory in order to enable geospatial analysis within quite a number of societal challenges. The increasing role of geo-information in disaster management nowadays consequently needs to include geospatial aspects on its analysis. Therefore different geospatial datasets can be combined in order to produce reliable geospatial analysis especially in the context of disaster preparedness and emergency response. A very well-known issue in this context is the fast delivery of geospatial relevant data which is expressed 
by the term \u201cRapid Mapping \u201d. Unmanned Aerial Vehicle (UAV. Giordan et al., 2018 try to find other ways to produce flooded map area with low cost multi-scale and multisensor to find suitable techniques fit to needs. This paper tries to shows what can be produced from 1-day survey and the simple used of GIS analysis for solving the flood problem in the village level.

Flood is the most widely growing disaster in the world related to 1980-2011 data (UNISDR, 2012). Floods hit almost all countries globally, especially in urban areas. This is happening due to the rapid development as a consequence of migration, as people seek opportunities from cities offer. It is estimated that flood affects 2.3 billion people worldwide and occurs in Asia and Africa more than on other continents (CRED, 2015). The threat of catastrophic floods is highest in the tropics like southern Asia, where populations are not just more exposed to floods, but maybe particularly vulnerable due to their social and economic characteristics. One of the common problems by the urbanisation in developing countries like Indonesia that aggravate to floods is the development of illegal settlements which are usually located in the river floodplain area. This becomes a big problem because Indonesia has lots of rivers.

A large number of rivers in Indonesia make the process of monitoring rivers and the environment around the river to be essential. As we know, one of the human civilisations developed through river civilisation. Continuous developments cause problems in the river system and social life around it. The problem that occurs is the change of land along the river (from forest to agricultural land and then to settlement) which generally starts from downstream to upstream of the river. Adaptation to a changing environment is needed as a part of the solution. Adaptation to disasters occurring due to climate change, such as floods, is done not only by individuals who are victims or at risk of becoming victims, but also by the government on behalf of society (Adger et al., 2003). The development of the adaptation process in government that pay attention to disaster risk is one of the goals to achieving Sendai Framework DRR. With rapid growth, the mapping of river areas for disaster mitigation and disaster response needs will be more effective if using updated maps so that they can show the condition of the disaster or the current situation of the location that is considered prone to disaster. This research shows that local governments, especially at the village level, can quickly make decisions using rapid mapping methods using drones.

\subsection{Location Description}

The research location is in Desa Way Galih, South Lampung, Lampung Province. Way Galih Village was chosen because it is the closest village to the gate exit of the new Trans Lampung toll road and close to the Campus of the Sumatra Institute of Technology (ITERA) as shown in Figure 1. This area is expected to grow rapidly shortly due to campus development and ease of toll access. This village has problems related to frequent flooding and inundation on access roads due to rain. Way Galih village itself consists of several parts called dusun. Criteria for selecting dusun locations as a research area are; quite dense population, some of the areas is close to the main road and close to the river as the end of the water flow. The research area is approximately $30 \mathrm{Ha}$.

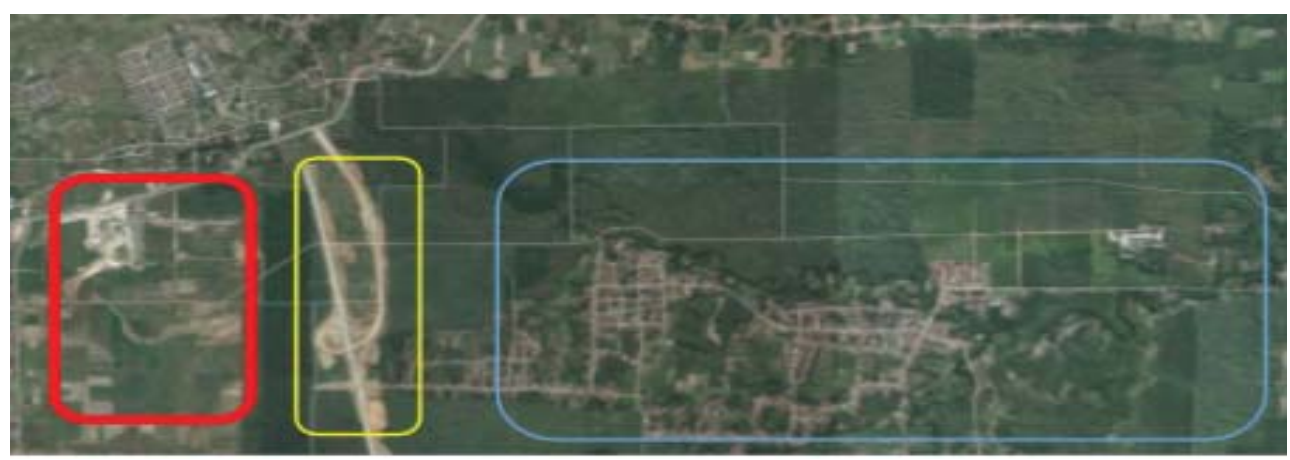

Figure 1. Way Galih Village (blue) relative to New Toll Road (yellow) and ITERA campus (red). 


\section{Research Method}

This research focuses on data retrieval using commercial drones which currently have a market price of less than 20 million rupiahs. Mapping (or maybe only capturing scene) using the drone is now very popular because of its operational ease and ability to do data snippets over large areas in a short time. This study uses DJI Phantom 4 drones for aerial photography. A DJI Phantom 4 drone technical specification is shown in Table 1. This drone is a quadcopter type. This type of drones has a stable advantage when retrieving data, but has a weakness of very short flight times. This deficiency causes the data retrieval process to be longer than the fixed-wing drone type.
This rapid mapping process is planned to be carried out within one day from morning to evening with the final results in the form of a 3D map and analysis maps are produce (apart from planning and preparation). The stage of aerial image acquisition is planned to be carried out by the society that have the commercial drone. This is because with the help of the latest developed technology make citizen participation to data crowdsourcing is possible (Assumpção et al., 2018). The data acquisition using drone requires clear weather. This is due not only to the limited equipment that cannot fly when it is drizzling and windy, but also because the camera requires clear sunlight to produce good photos. The flow of the implementation of this research shown in Figure 2.

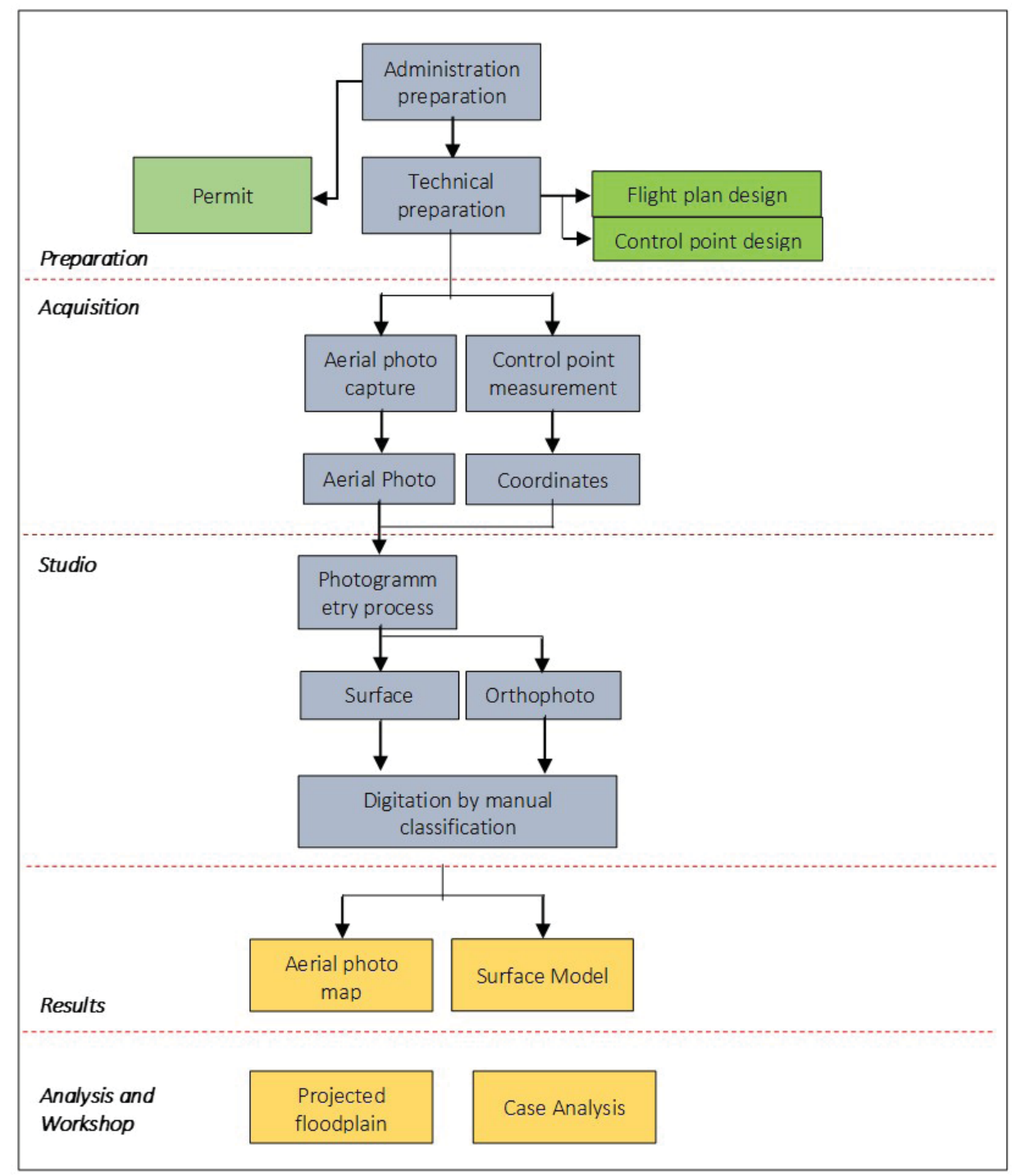

Figure 2. Research Flowchart. 
A Control point is needed to correct the photo result so the photo can have geometry and dimension. Even though the drone is equipped with internal GPS, but it still has poor quality. Control points are points that can be identified in the field and the photo. The process of selecting this control point can be done beforehand by placing a sign in the field (premark), or after measurement by identifying objects on the photo (photo point). The disadvantage of the photo point process is that we cannot choose where allied point locations will be stored because not necessarily in the desired location there are objects that can be identified. Therefore, in this study, we conducted a premark installation in the previous field with materials that were last for approximately 1 (one) month. The material used is plastic-like for banner. Control points are divided into Ground Control Points (GCP) and Independent Control Points (ICP). The difference between GCP and ICP lies in the involvement of these points in processing. GCP is a point used to produce a model and is involved in processing and ICP is used to check the results of image processing. The premark installed in the field is cross-shaped as shown in Figure 3. The time needed to place the premark across the area is within half-hour.

Table 1. Technical Specification of DJI Phantom 4 and Camera (source: dji.com)

\begin{tabular}{ll}
\hline AIRCRAFT & \\
\hline Weight (Battery \& Propellers Included) & $1380 \mathrm{~g}$ \\
Max Ascent Speed & S-mode: $6 \mathrm{~m} / \mathrm{s}$ \\
Max Descent Speed & S-mode: $4 \mathrm{~m} / \mathrm{s}$ \\
Max Speed & S-mode: $20 \mathrm{~m} / \mathrm{s}$ \\
Max Tilt Angle & S-mode: $42^{\circ}$ \\
& A-mode: $35^{\circ}$ \\
& P-mode: $15^{\circ}$ \\
Max Angular Speed & S-mode: $200^{\circ} / \mathrm{s}$ \\
& A-mode: $150^{\circ} / \mathrm{s}$ \\
Max Service Ceiling Above Sea Level & 19685 feet $(6000 \mathrm{~m})$ \\
Max Wind Speed Resistance & $10 \mathrm{~m} / \mathrm{s}$ \\
Max Flight Time & Approx. $28 \mathrm{minutes}$ \\
Operating Temperature Range & $32^{\circ}$ to $104^{\circ} \mathrm{F}\left(0^{\circ}\right.$ to $\left.40^{\circ} \mathrm{C}\right)$ \\
Satellite Positioning Systems & GPS $/ \mathrm{GLONASS}$ \\
\hline CAMERA & \\
\hline Sensor & $1 / 2.3^{\prime \prime} \mathrm{CMOS}$ \\
& Effective pixels: $12.4 \mathrm{M}$ \\
Lens & FOV $94^{\circ} 20 \mathrm{~mm}(35 \mathrm{~mm}$ format equivalent $) \mathrm{f} / 2.8$ focus at $\infty$ \\
ISO Range & $100-3200$ (video $)$ \\
Electronic Shutter Speed & $100-1600$ (photo $)$ \\
Image Size & $8-1 / 8000 \mathrm{~s}$ \\
Photo & $4000 \times 3000$ \\
Operating Temperature Range & JPEG, DNG $(\mathrm{RAW})$ \\
\hline & $32^{\circ}$ to $104^{\circ} \mathrm{F}\left(0^{\circ}\right.$ to $\left.40^{\circ} \mathrm{C}\right)$ \\
\hline
\end{tabular}

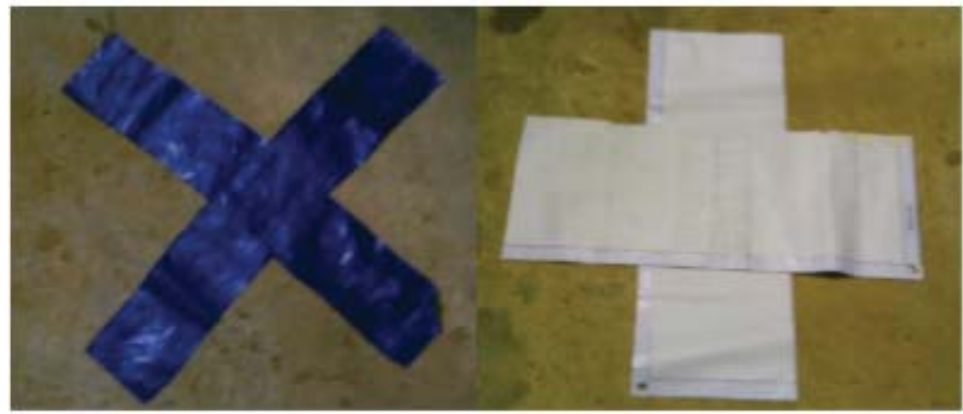

Figure 3. Type of the premark. 


\subsection{Control point survey}

After the premark has been installed, it is then measured by a Geodetic GPS device to produce definitive coordinates. The GPS survey process is carried out by the radial method and is tied to the tie point (benchmark with definitive coordinate) on the ITERA campus. The tool used in this measurement process is the Topcon Hiper II GNSS that can capture GPS and GLONASS signals. The measurement process takes 10 minutes for each point. The data obtained is then downloaded and then processed using Topcon Tools software. This process needs approximately three hours to complete.

Table 2. List of control point.

\begin{tabular}{lll}
\hline LABEL & \multicolumn{1}{c}{ LONGITUDE } & \multicolumn{1}{c}{ LATITUDE } \\
\hline point 1 & $105^{\circ} 20^{\prime} 53.3625^{\prime \prime} \mathrm{E}$ & $5^{\circ} 21^{\prime} 50.1116^{\prime \prime} \mathrm{S}$ \\
point 2 & $105^{\circ} 21^{\prime} 2.5256^{\prime \prime} \mathrm{E}$ & $5^{\circ} 21^{\prime} 49.5116^{\prime \prime} \mathrm{S}$ \\
point 3 & $105^{\circ} 21^{\prime} 8.7730^{\prime \prime} \mathrm{E}$ & $5^{\circ} 21^{\prime} 48.7447^{\prime \prime} \mathrm{S}$ \\
point 4 & $105^{\circ} 20^{\prime} 55.2429^{\prime \prime} \mathrm{E}$ & $5^{\circ} 21^{\prime} 55.7876^{\prime \prime} \mathrm{S}$ \\
point 5 & $105^{\circ} 21^{\prime} 1.6294^{\prime \prime} \mathrm{E}$ & $5^{\circ} 21^{\prime} 53.5988^{\prime \prime} \mathrm{S}$ \\
point 6 & $105^{\circ} 21^{\prime} 6.9233^{\prime \prime} \mathrm{E}$ & $5^{\circ} 21^{\prime} 54.0568^{\prime \prime} \mathrm{S}$ \\
point 7 & $105^{\circ} 21^{\prime} 9.1351^{\prime \prime} \mathrm{E}$ & $5^{\circ} 21^{\prime} 57.9118^{\prime \prime} \mathrm{S}$ \\
point 8 & $105^{\circ} 21^{\prime} 2.7487 ” \mathrm{E}$ & $5^{\circ} 21^{\prime} 56.7982^{\prime \prime} \mathrm{S}$ \\
point 9 & $105^{\circ} 20^{\prime} 56.7490^{\prime \prime} \mathrm{E}$ & $5^{\circ} 22^{\prime} 1.0409^{\prime \prime} \mathrm{S}$ \\
point 11 & $105^{\circ} 21^{\prime} 7.3293^{\prime \prime} \mathrm{E}$ & $5^{\circ} 21^{\prime} 43.2260^{\prime \prime} \mathrm{S}$ \\
point 10 & $105^{\circ} 21^{\prime} 3.6733^{\prime \prime} \mathrm{E}$ & $5^{\circ} 21^{\prime} 44.2224^{\prime \prime} \mathrm{S}$ \\
\hline
\end{tabular}

The transformed coordinates are then used as control points identified in aerial photography in Agisoft software. In the measurement process, the GPS is not allowed to be held using pole but must use a tripod. The use of tripod aims to result in less movement GPS so it can produce accurate data. This survey takes time a lot, and need a survey skill and knowledge on GPS processing.
This research still do the control point survey, the final processing build two different orthophoto one with control point and the other not. For the future it is assumed that for the continuous monitoring the control point data is available. List of the control point is shown in Table 2.

\subsection{Aerial photo processing}

Agisoft software is used to process the aerial images. This software requires a computer with medium to high specifications in terms of RAM memory, processor speed, and graphics card (VGA). Photo processing needs two hours in medium setting with core i7, 32GB RAM, and 4 dedicated VGA computer. The number of photos produced is approximately 600 photos, quite large for a relatively small area. The captured photo cannot be used immediately and still require some corrections. In this study corrections were carried out with the following stages:

a. Tilted photo correction by checking photos against the horizon. The aim of the correction is to make sure there are no slanted or tilted photos.

b. Blurry photos selection by looking for photos that is blurry or not focused. Unfocused photos cannot be used in the treatment process because they cannot be identified.

c. Photo colour correction by sharpening and adjust brightness settings. This process can be done automatically using the image processing software like Microsoft Office Picture Manager or GIMP.

After the correction process is carried out, the flow stages of aerial photo processing follow the stages as shown in the Figure 4.

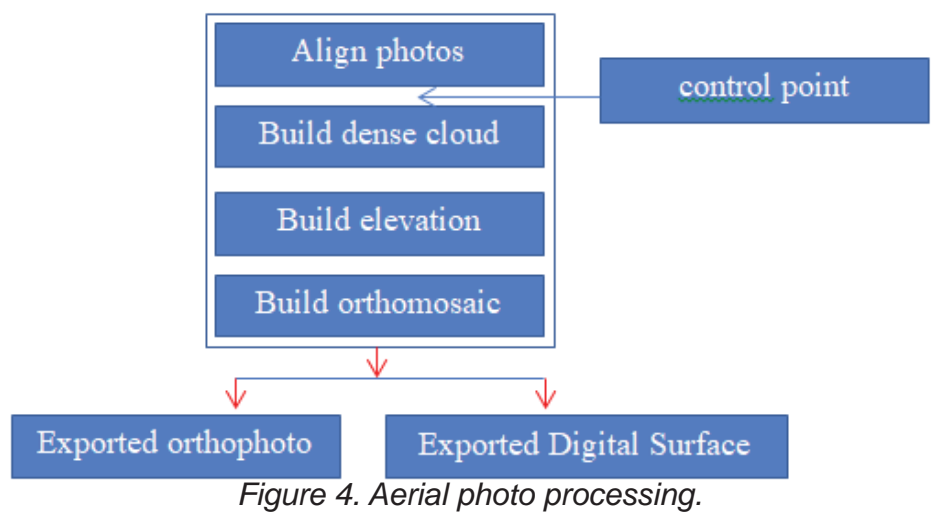




\subsection{Zoning Analysis}

Comprehensive, systematic and multidisciplinary analysis is needed to understand the impacts and causes of disaster. This necessity creates an innovative framework for adaptive and integrated disaster resilience (AIDR). This is defined as an ability of nations and communities to build resilience in an integrated manner and strengthen mechanisms to build system adaptiveness (Djalante et al., 2013)deadly and costly disasters. Disasters are increasingly uncertain and complex due to rapid environmental and socio-economic changes occurring at multiple scales. Understanding the causes and impacts of disasters requires comprehensive, systematic and multi-disciplinary analysis. This paper introduces recent multidisciplinary work on resilience, disaster risk reduction (DRR. There are 7 (seven) conceptual tools to achieve AIDR. One of them is to strengthen the capacity of polycentric governance, the multipolitical jurisdiction at different governance scale, to increase best local knowledge of hazards and vulnerability. The best suitable level to strengthen is at the village level. To accomplish the mission, the village need to support by the information, especially spatial information. Supported with good and up to date information of their geography, they can make decisions about spatial planning on their level. The Government of Indonesia with the Geospatial Information Act of 2011 try to regulate the spatial data synchronisation in Indonesia through One Map Policy. One of the products of the one map policy is the Village Map.

The purpose of making village maps is to help village officials or village communities recognise the characteristics of their villages so that the development process can be well directed. For this reason, knowledge is needed regarding the existing zoning rules that apply in Indonesia. The zoning regulations are the provisions governing the requirements for spatial use and its control provisions and are compiled for each designation zones/ zones which are stipulated in a detailed spatial plan (PP NO.26 / 2008 concerning RTRWN article 1 number 27). One of the main analyses is to project the location of the inundation possibility in the area of the river that crosses to the research location. This research implement zoning analysis with a case analysis for determines the exact location for a flood-free biogas digester. Biogas is an example for zoning analysis because biogas is listed in the Lampung Provincial Government master plan for energy security. Condition of the village area that still has a lot of agricultural land and livestock as a primary raw material to supporting biogas increase the need for zoning analysis. The problem needs to be solved for biogas is about where the safe from inundation but still meets the criteria from the regulation.

\section{Results and Discussion}

\subsection{Aerial Orthophoto Result}

Align Photos process by reconstructing the path of light over two photos to make a model depend on the flight path. In this study, the flight path used was a manual free flight, not an automatic flight path by design. Although many applications can make an automaticflight plan with only entered a command into the drone system, yet this action needs knowledge of basic calculation for a different type of aerial photo survey. This study is expected that aerial photo measurement data will be carried out crowdsource by community's who have commercial drones. In photogrammetry theory, types of the flight plan are influenced by how many sensors they have and how much scale the map will produce. In this study, technical matters related to the material try to be simplified. We know that the average commercial drone has a camera sensor size of 12 Mega Pixels, and the flying height that is allowed by the regulation is 150 meters. With the FC330 camera specifications that has a focal length of 3.61, pixel size width of 3856 pixels, pixel size height of 2795 pixels, overlap of around $70-80 \%$, side-lap range of $60 \%$, and flying height not more than 150 meters, it will give maximum resolution around 4 to $5 \mathrm{~cm} /$ 
pixel. Figure 5 shows the difference between the flight plan made with the Mission Planner application and the flight plan (actually flight trace) from the manual free flight.

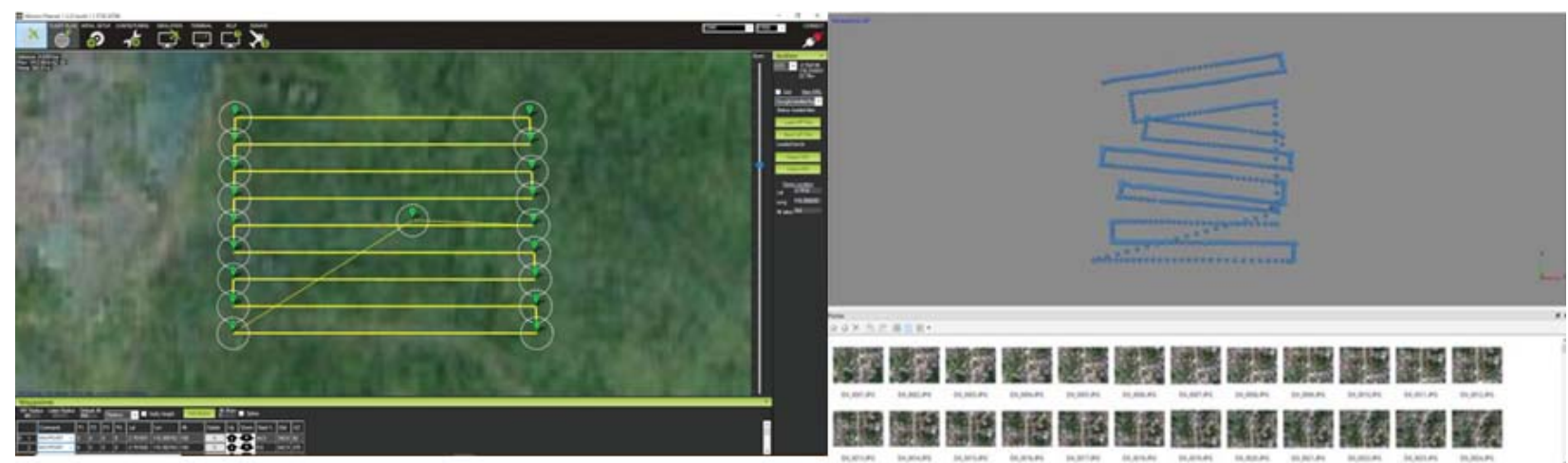

Figure 5. Flight plan with Mission Planner (left) and flight trace from the free flight (right).
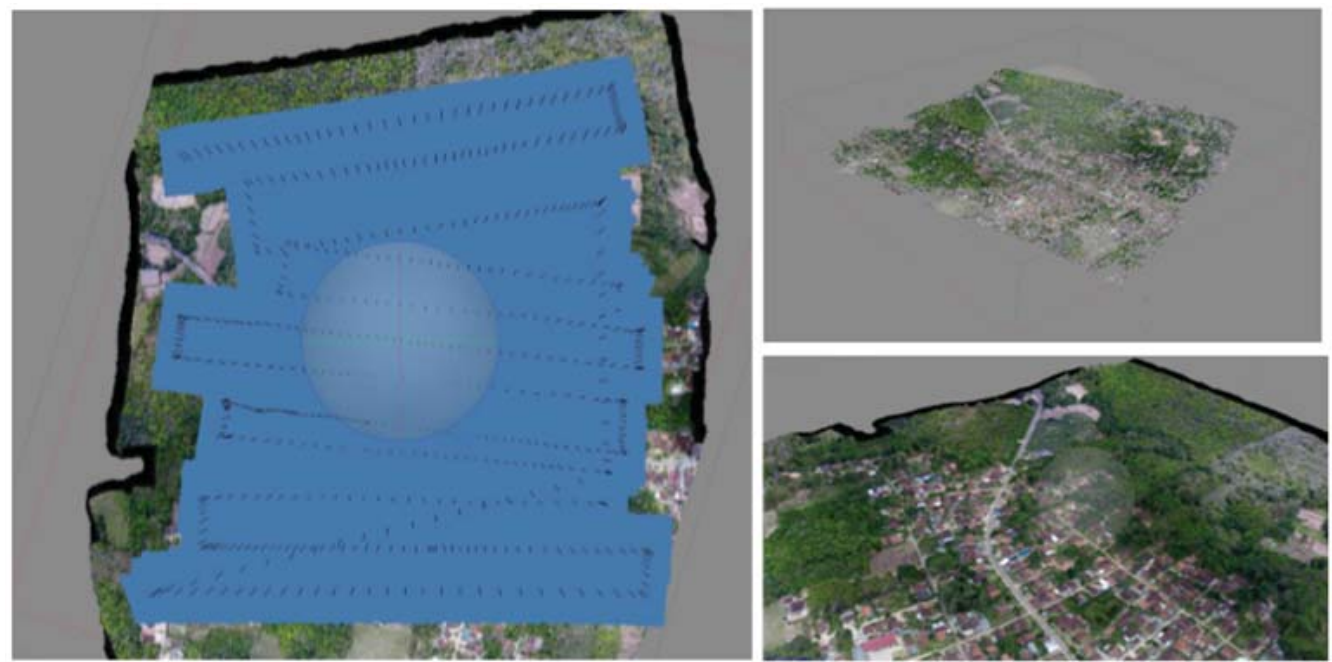

Figure 6. Align photos and build dense cloud.

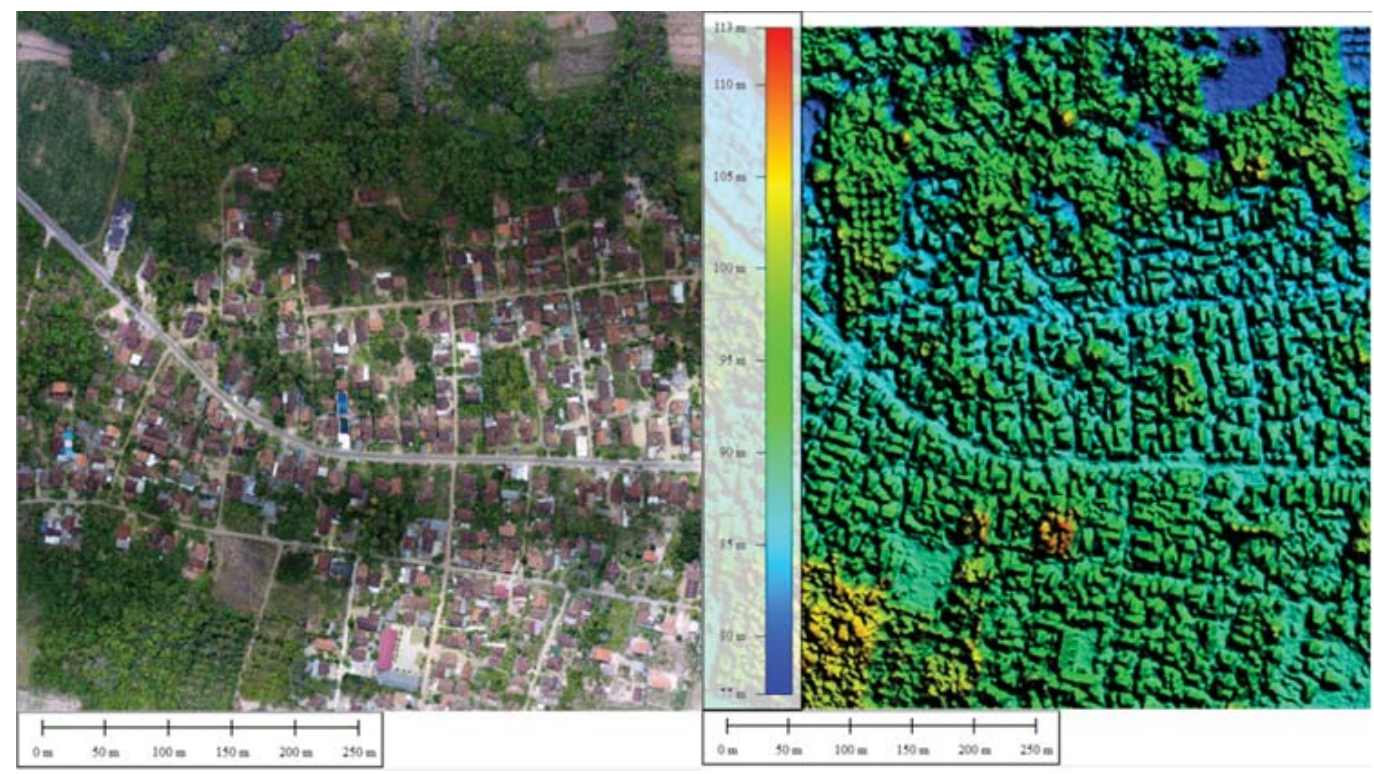

Figure 7. Aerial orthophoto (left), Digital Surface Model (right). 
The align photo and build dense cloud process aim to see the results of the formation of the initial model from a pair of photos. The processed results show that the photo model can be appropriately formed. This is because the large numbers of photos create the overlap and side-lap properly. Figure 6 shows the results of the overlay of the photo (blue area) and the align photo and build dense cloud process (right photos).

The photo processing process uses two types; the first one is photos that are processed without control points, and photos with control points. All the process takes two hours. The results of processing without a control point will have low accuracy because there is no correction given, although it can still provide an overview of the shape of the research area. The assumption used is if the research location cannot be accessed to measure control points, and also the ease and speed of the results given without a tie point. The resulting orthophoto and DSM results can be seen in the Figure 7.

\subsection{Floodplain Analysis and Case Analysis of the Biogas Digester Location}

To be able to analyse the projections for determining the location of flood inundation, a classification of the area whose information is derived from the map is needed through the digitisation process. The purpose of the classification is to obtain general information, namely roads, buildings, rivers, and open areas. Determination of floodplain location is done by using actual inundation event data that occurred before on the model. The simulation results show which locations are most likely to be affected by the inundation even though at this time the location has not been affected by flooding because buildings and trees still block the water.
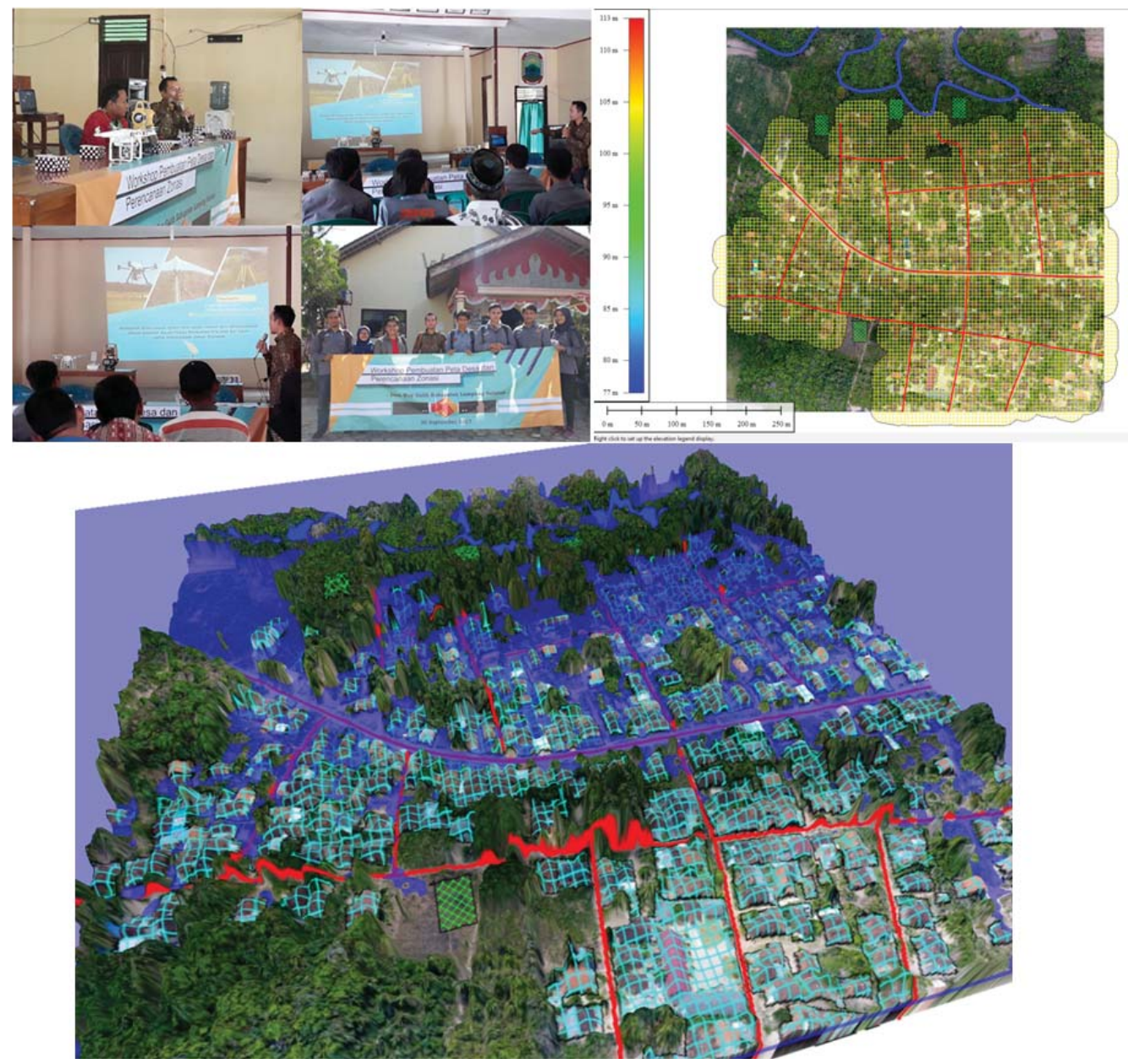

Figure 8 Workshop (top left), Proposed digester location (top right), Analysis of floodplain and final best digester location (bottom). 
From the discussions with residents and government officials, the level of flood inundation problems is only categorised as a disturbing event, not a disaster. For this reason, the study tries to raise the awareness of citizens as well that these conditions cannot be continuously considered as a nuisance, but must be minded out for along with the development of the village. One of the cases raised was the development of the independent village with renewable energy from biogas sources. Analysis carried out is to determine the location of the biogas digester that is by the requirements but free from flood inundation hazards. The criteria used are; 1. Dumpster area, 2. Maximum 20 meters to the nearest fountain, 3. Location for a biogas plant with $20 \times 30 \mathrm{~m}$ size, 4 . Waste disposal location, 5. Maximum 20 meters to the nearest house, 6. Flood free. The analysis run by the overlay method with input classification data and required criteria.

The analysis was accomplished with village officials through GIS workshops held in the afternoon for approximately two hours. The analysis process is carried out by the operator with input information from the village official. This workshop also introduces the use of digital maps through applications, as well as maps through smartphones (Google maps) that they have. To help the process of transferring information, a printed map from drone measurements is also provided. The results of the flood location analysis and case analysis of the location of the biogas digester are shown on the Figure 8.

In Figure 8, the reference water level is obtained from villager reports that the main village road and the alley in front of the house are often flooded during the rainy season. From Figure 8 it can be seen that almost all settlements in the northern part of the village's main road were flooded. The results of the analysis also show from four proposed locations for the location of the biogas digester, three of which are in the inundation area.

\subsection{Discussion}

The purpose of the research is to try to develop rapid mapping techniques, one of which is by involving the community in data retrieval using commercial drones owned. However, even though the research has tried to simplify the process of the acquisition and processing, there are still some things that require attention, namely:

1. The results of photo processing show that even with the free flight method, basic knowledge is still needed regarding the science of photogrammetry. This is important so that the data acquisition process in next future through the crowdsource method still comply with the standard map-making.

2. The control point measurement process still cannot be carried out by the public or the community, so accurate coordinate control point data must still be provided. Processing without control points can be done to produce a general overview of the location.

3. Processing aerial photographs to produce orthophoto and DSM still requires special and paid software. Cloud computing technology by uploading photo data from the aerial survey, maybe a solution in the future..

Regarding flood analysis, three proposed biogas digester locations were chosen because they were close to the river. The hope is that the river will help water needs for the biogas manufacturing process. Whereas from the analysis, the location is vulnerable to the possibility of being damaged by floods. This shows a common problem that occurs that human activities need rivers to develop, but rivers can also be a threat to these developments. The process of adaptation and use of flood infrastructure technology is very necessary to be developed in line with the development of technological development itself. Furthermore, the integration of flood management with spatial planning is urgently needed. 


\section{Conclusion}

The results of the study show that commercial drones and one day are enough to create a village map and simple flood analysis. The break downtime consumed are; a. Half an hour for Premark installation, b. Two hours of control point measurement, c. One hour download and processing of control point data, d. Half an hour of shooting and downloading photos, e. two hours processing medium-quality aerial photographs, f. twohour workshop on analysis of results. The results of the mapping facilitate the analysis of flood locations and the determination of the location of digester by policymakers, in this case, the village authorities. Thus, the use of commercial drones and rapid mapping techniques can help realise proper DRR implementation to prevent causal factors of the flood.

\section{Acknowledgements}

This research is fully support by Institut Teknologi Sumatera (ITERA) as an output of research grant year 2017. Thank you for all the Dusun 3 official authority, students of Geomatic Engineering, and students of Regional and City Planning for all the support.

\section{References}

Adger, W. N., Huq, S., Brown, K., Conway, D., \& Hulme, M. (2003). Adaptation to climate change in the developing world. Progress in Development Studies, 3(3), 179-195. https:/ / doi. org/10.1191/1464993403ps060oa

Aitsi-Selmi, A., Egawa, S., Sasaki, H., Wannous, C., \& Murray, V. (2015). The Sendai Framework for Disaster Risk Reduction: Renewing the Global Commitment to People's Resilience, Health, and Well-being. International Journal of Disaster Risk Science, 6(2), 164-176. https:/ / doi.org/10.1007/s13753-015-0050-9

Assumpção, T. H., Popescu, I., Jonoski, A., \& Solomatine, D. P. (2018). Citizen observations contributing to flood modelling: opportunities and challenges. Hydrology and Earth System Sciences, 22(2), 1473-1489. https:// doi.org/10.5194/ hess-22-1473-2018

CRED. (2015). The Human Cost of Weather Related Disaster 1995-2015. Retrieved from https:/ / www. unisdr.org/2015/docs/climatechange/COP21_WeatherDisastersReport_2015_FINAL.pdf

Djalante, R., Holley, C., Thomalla, F., \& Carnegie, M. (2013). Pathways for adaptive and integrated disaster resilience. Natural Hazards, 69(3), 2105-2135. https://doi.org/10.1007/s11069-0130797-5

dji.com. (2017). Phantom 4. Retrieved from https:/ /www.dji.com/uk/phantom-4/info

Feng, Q., Liu, J., \& Gong, J. (2015). Urban Flood Mapping Based on Unmanned Aerial Vehicle Remote Sensing and Random Forest Classifier - A Case of Yuyao, China. Water . https:/ / doi.org/10.3390/w7041437

Giordan, D., Notti, D., Villa, A., Zucca, F., Calò, F., Pepe, A., ... Allasia, P. (2018). Low cost, multiscale and multi-sensor application for flooded area mapping. Natural Hazards and Earth System Sciences, 18(5), 1493-1516. https:/ / doi.org/10.5194/nhess-18-1493-2018

Griffin, G.F. (2014). The Use of Unmanned Aerial Vehicles for Disaster Management. GEOMATICA, 68(4), 265-281. https://doi.org/10.5623/cig2014-402

Smith, L. C. (1998). Satellite remote sensing of river inundation area, stage, and discharge: a review. Hydrological Processes, 11(10), 1427-1439. https://doi.org/10.1002/(SICI)10991085(199708)11:10<1427::AID-HYP473>3.0.CO;2-S

Tampubolon, W., \& Reinhardt, W. (2015). Uav Data Processing for Rapid Mapping Activities. 
The International Archives of the Photogrammetry, Remote Sensing and Spatial Information Sciences, XL-3/W3. Retrieved from https://www.unibw.de/geoinformatik/mitarbeiter/ pdf-dateien-tampubolon/isprsarchives-xl-3-w3-371-2015.pdf

UNISDR. (2004). Living With Risk: A Global Review of Disaster Reduction Initiative. (Terry \& Jegg, Eds.) (1st ed.). United Nations. https:/ / doi.org/ISBN 92-1-101064-0

UNISDR. (2012). Number of Climate-related DIsaster Around the World (1980-2011). Retrieved from https:/ / www.preventionweb.net/files/20120613_ClimateDisaster1980-2011.pdf

Wahlström, M. (2015). New Sendai Framework Strengthens Focus on Reducing Disaster Risk. International Journal of Disaster Risk Science, 6(2), 200-201. https://doi.org/10.1007/s13753015-0057-2 